\title{
Wanita Bekerja dan Pengambilan Keputusan (Studi Kasus Pada 8 Guru Wanita SMPN di Desa Karumbu Kecamatan Langgudu Kabupaten Bima)
}

\author{
St. Nurbayan ${ }^{1}$ dan Syaifullah ${ }^{2}$ \\ Program Studi Pendidikan Sosiologi STKIP Bima \\ Jalan Piere Tendean Kel. Mande Tlp.Fax (0374) 42801, Bima 84191, Indonesia \\ email; nurbayan.st@gmail.com \\ syaifullahsosiologi@gmail.com
}

\begin{abstract}
Abstrak
Sejak jaman purbakala perempuan telah mengenal berbagaimacam pekerjaan, baik bekerja dalam rumah tangga, maupun bekerja diluar rumah tangganya, namun sangat sedikit dilibatkan dalam pengabilan keputusan, begitupun juga dengan wanita bekerja sebagai guru PNS SLTP di Desa Karumbu Kecamatan Langgudu Kabupaten Bima NTB. Oleh karena itu penelitian ini bertujuan untuk mendeskripsikan kehidupan wanita bekerja dan pengambilan keputusan baik dalam rumah tangga maupun dalam instansi tempat mereka bekerja, informan penelitian 8 orang guru SLTP yang berada pada SMPN dan MTsN di Desa Karumbu yang ditentukan engan teknik purposive sampling. Pengumpulan data dengan wawancara mendalam, lalu dianalisis dan membuat kesimpulan. Penelitian ini menunjukkan bahwa (1) perempuan bekerja karena mencukupi kebutuhan keluarga dan memanfaatkan ilmu (ijazah) yang telah dimilikinya. Alokasi waktu wanita bekerja rata-rata mulaipukul 04.00-07.00 menyiapakan menu makan keluarga, memastikan kerapian pakaian kerja suami dan pakaian sekolah anak, memandikan anak lalu menyiapkan diri untuk bekerja, pukul 07.30-13.00 bekerja, sepulang di rumah rata-rata mengurus urusan rumah sampai pukul 21.00, diantaranya mencuci dan menyetrika, pembersihan rumah dan halamannya, menyiapkan menu makan siang dan makan malam, menemani anak belajar dan mengaji, melayani suami dengan makanan dan kopi siap saji, hal ini dilakukan bukan karena merasa ada kewajiban, tetapi karena tidak ada yang bisa melakukannya, sementara suami menganggap urusan rumah dan pengasuhan anak adalah tugas istri. Untuk penentuan keputusan wanita jarang dilibatkan dalam dunia kerjanya, karena semuanya kebijakan ada ditangan pimpinan, kemudian dalam rumah tangga rata-rata pengambilan keputusan hanya pada sekitar menu makan. namunhanya 3 wanita yang dilibatkan pada urusan perumahan, pendidikan dan kesehatan.
\end{abstract}

Kata Kunci : Wanita Bekerja, Pengambilan Keputusan. 


\section{Pendahuluan}

Fenomena wanita bekerja sebenarnya bukanlah hal yang baru di tengah masyarakatIndonesia. Sejak zaman purba ketika manusia masih mencari penghidupan dengan cara berburu dan meramu, seorang isteri sesungguhnya sudah bekerja. Sementara suaminya pergi berburu, di rumah wanita bekerja menyiapkan makanan dan mengelola hasil buruan untuk ditukarkan dengan bahan lain yang dapat dikonsumsi keluarga, karena sistem perekonomian yang berlaku pada masyarakat purba adalah sistem barter, maka pekerjaan perempuan meski sepertinya masih berkutat di sektor domestik namun sebenarnya mengandung nilai ekonomi yang sangat tinggi. Kemudian ketika masyarakat berkembang menjadi masyarakat agraris hingga menjadi masyarakat industri, keterlibatan wanita pun sangat besar. Bahkan dalam masyarakat berladang berbagai suku di dunia, yang banyak menjaga ternak dan mengelola ladang dengan baik itu adalah kebanyakan wanita. Sejalan dengan itu, William J. Goode (2002:153) mengatakan bahwa "wanita dari dulu sudah bekerja tetapi baru pada masyarakat industri moderenlah mereka itu berhak memasuki pasaran tenaga kerja sendiri untuk memperoleh pekerjaan dan promosi tanpa bantuan atau perkenan para lelaki”.

Ini berarti bahwa dalam konteks Indonesia sebagai negara berkembang, sebenarnya tidak ada wanita yang benarbenar menganggur. Biasanya para wanita memiliki pekerjaan untuk memenuhi kebutuhan rumah tangganya entah itu mengelolah sawah, membuka warung di rumah, mengkreditkan pakaian dan lainlain, karena wanitalah yang langsung merasakan ketika kebetuhan-kebutuhan hidup seperti menyangkut kesehatan, gizi keluarga, pendidikan anak dan pengeluaran biaya hidup tidak tercukupi. Hanya saja sebagian besar masyarakat Indonesia masih beranggapan bahwa wanita dengan pekerjaan-pekerjaan tersebut bukan termasuk kategori wanita bekerja, karena menganggap wanita bekerja identik dengan wanita karir. Meskipun bukan fenomena baru, namun masalah wanita bekerja nampaknya masih terus menjadi perdebatan sampai sekarang, karena bagaimanapun, masyarakat masih memandang keluarga yang ideal adalah suami bekerja di luar rumah dan isteri di rumah dengan mengerjakan berbagai macam pekerjaan rumah.

Anggapan tersebut merupakan anggapan negatif (stereotyp) yang kuat di masyarakat karena masih menganggap idealnya suami berperan sebagai pencari nafkah, dan pemimpin yang penuh kasih, sedangkan istri menjalankan fungsi pengasuhan anak, mengurus segala keperluan rumah tangga. Sejalan dengan ini, Dwi J. Narwoko (2007:342) mengatakan bahwa "anggapan stereotip adalah pelabean terhadap pihak tertentu yang selalu berakibat merugikan pihak lain dan menimbulkan ketidak keadilan". Ini berarti bahwa salah satu stereotip yang dikenalkan dalampembahasan ini adalah stereotip yang menganggap bahwa wanita cocoknya kerja dirumah dan mengurus anak-anaknya dan kurang baik bekerja diluar rumah. Seiring dengan perkembanganzaman, tentu saja peranperan tersebut tidak semestinya dibakukan,terlebih kondisi ekonomi yang membuat kita tidak bisa menutup mata bahwa kadang-kadang istripun dituntut untuk harus mampu juga berperan sebagai pencari nafkah. Walaupun seringkali kita dengar jika seorang laki-laki atau suami ditanya maka akan muncul jawaban "Seandainya gaji saya cukup, saya lebih suka isteri saya di rumah merawat anakanak".

Terlepas dari pembahasan di atas, perdebatan mungkin muncul lebih karena anggapan akan stereotip dari masyarakat bahwa akan ada akibat yang timbul jika suami-isteri bekerja di luar rumah yaitu mengganggu keharmonisan keluarga, namun solusi yang diambil tidak 
semestinya membebankan istri dengan dua peran sekaligus yaitu peran mengasuh anak (nursery) dan mencari nafkah di luar rumah (provider), yang akan lebih membebankan perempuan, tetapi adanya dukungan sistem yang tidak terus membawa perempuan pada posisi yang dilematis,karena adanya pandangan yang mengarahkan agar wanita harus menyadari dan mengakui nilai dan kekuatan serta kemampuan dirinya dalam hal melakukan apapun seperti halnya kaum laki-laki. Salah satunya adalah kaum Feminis Redikal menolak tanggapan patriarki yang melihat diri wanita itu lemah dan bergantung, sehingga Ritzer, (2007:433) mengatakan bahwa "selain itu ada pula tuntutan kesetaraan gender dan programprogram pendekatan pembangunan yang telah membantu perempuan untuk berpartisipasi dalam kegiatan politik, ekonomi, sosial budaya, pertahanan dan keamanan nasional, dan kesamaan dalam menikmati hasil pembangunan".

Hal ini dapat diperkuat oleh kaum Feminis Liberal (Ritzer, 2007:420) menggambarkan bahwa "perempuan bisa mengklaim kesamaan dengan laki-laki atas dasar kapasitas esensial manusia sebagai agen moral yang bernalar dalam aktualisasi diri dan mengusulkan bahwasannya perempuan mempunyai hak yang sama dengan laki-laki". Ini berarti bahwa wanita bukanlah manusia yang lemah yang selalu bergantung pada lakilaki, karena wanita juga mampu bekerja, berpartisipasi dalam kegiatan politik, ekonomi, sosial budaya, pertahanan dan keamanan nasional, dan kesamaan dalam menikmati hasil pembangunan seperti halnya kaum pria, sehingga pekerjaan, mengekpresikan diri dan mengembangkan diri merupakan kebutuhan yang sangat berharhga bagi wanita, sehingga wanita juga tidak merasa diremehkan.Bekerja merupakan salah satu sarana yang dapat digunakan oleh kaum wanita, mengekspresikan diri dan mengembangkan diri dengan orang lain serta membagi ilmu dan pengalaman, menemukan sesuatu dan menghasilkan sesuatu, serta mendapatkan penghargaan atau prestasi karena setiap manusia pasti mempunyai kebutuhan akan aktualisasi diri dan menemukan makna hidupnya melalui aktivitas yang dijalaninya.

Tampilnya ibu rumah tangga sebagai pekerja merupakan suatu upaya untuk menerobos tirai tradisi yang selama ini menganggap bahwa tempat kaum wanita adalah dirumah mengurus anak dan melayani suami. Adanya kemajuan pendidikan dan teknologi seperti sekarang tidak lagi membedakan antara tenaga kerja pria atupun wanita, karena yang menjadi ukuran adalah tingkat penguasaan ketrampilan yang sesuai dengan kebutuhan pasar tenaga kerja. Semua ini sebagai suatu pertanda bahwa kaum pria dan wanita mempunyai hak dan kedudukan yang sama dalam memperoleh pekerjaan. Namun demikian, ada kondisi yang tidak bisa dipungkiri bahwa wanita mempunyai peran kodrati dimana suatu waktu tertentu wanita meninggalkan pekerjaannya untuk beberapa hari karena melahirkan. Selain itu dituntut pula penyediaan waktu mengurus anak-anaknya paling tidak untuk menyusui, kemudia dituntut pula untuk senantiasa mengatur kebutuhan anak dirumah. Pertumbuhan dan perkembangan anak dirumah sangat menuntut kehadiran orang tua (ayah dan Ibu), hal ini dimaksudkan untuk memelihara adanya interaksi dan komunikasi yang akan menjadi suatu pola hubungan orang tua dan anak dalam satu keluarga yang utuh atau keluarga batin, yang diprediksi ikut mewarnai karakter dan pertumbuhan anak dikemudian hari.

Secara sosiologis proses ini adalah proses soialisasi dimana seorang anak begitu dilahirkan akan diperkenalkan dengan berbagai ragam, nilai-nilai sosial yang dianut oleh keluarga, tetangga ataupun masyarakat secara luas. Shadily (1983) mendefinisikan bahwa "sosialisasi sebagai suatu proses dimana seseorang 
mulai menerima dan menyesuaikan diri kepada adat-istiadat suatu golongan, dimana lambat laun ia akan merasa sebagian dari golongan itu". Dalam proses ini seseorang individu dari masa anak-anak sampai masa tuanya belajar pola-pola tindakan interaksi dengan segala macam individu sekelilingnya menduduki berbagai macam ragam peranan sosial yang ada dalam kehidupan sehari-hari.

Hasil penelitian Sheldon dan Eleanor Glueck (Abu Hamid, 2007:181) menunjukkan bahwa "banyak anak nakal yang berasal dari keluarga yang bersifat menolak atau acuh tak acuh terhadap anak. Anak-anak nakal yang berasal dari keluarga yang bersikap menolak ini umumnya mempunyai sifat curiga terhadap orang lain dan suka menentang kekuasaan, mereka tidak lagi terkesan oleh hukuman karena sudah terlalu banyak mengalami hukuman dari orang tuanya". Jadi, dampak semacam inilah yang dihindari dan dibutuhkan pola pengasuhan orang tua yang tepat terhadap pertumbuhan anak-anak, Dalam hal ini konsep AGI yang diperkenalkan oleh Talcott Parsons, (Suhendi, 2001) bahwa "dalam menganalisis tindakan sosial, dimana masa adaptasi (adaptation) anak mulai mengadakan penyesuaian diri dengan lingkungannya, reaksi yang dilakukannya tidak hanya datang dari dalam dirinya melainkan datang dari luar". Pada masa inilah peran orang tua sangat penting karena akan banyak membantu anak sehingga tidak meniru perbuatanperbuatan yang sifatnya tidak baik dalam proses pertumbuhannya.Hal inilah yang dilihat dalam penelitian ini, dimana seorang ibu rumah tangga yang bekerja diluar rumah sebagai guru pegawai negeri yang harus full time mengajar di sekolahsekolah. Tentunya dengan pekerjaan tersebut merupakan peran wanita yang cukup sulit dilakukan, namun sangat sedikit dilibatkan dalam pengambilan keputusanpengambilan keputusan.

\section{Tinjauan Pustaka}

\section{A. Status dan Peran Wanita}

\section{Wanita Sebagai Ibu dalam Rumah}

Oleh (Sofia R. Noor : 2006)

Peranan ibu di dalam mendidik anaknya dibedakan menjadi tiga tugas penting, yaitu ibu sebagai pemuas kebutuhan anak, ibu sebagai teladan atau "model" peniruan anak dan ibu sebagai pemberi stimulasi bagi perkembangan anak.

a. Ibu sebagai sumber pemenuhan kebutuhan anak

b. Ibu sebagai teladan atau model bagi anaknya.

c. Ibu sebagi pemberi stimuli bagi perkembangan anaknya

\section{Wanita Sebagai Istri}

Berbicara masalah peran ibu sebagai istri pendamping suami tentunya tidak lepas dari peran ibu sebagai ibu rumah tangga. Hal ini (Sofia R. Noor, 2006) menggambarkan bahwa peran yang pokok seorang wanita sebagai pendamping suami antara lain: Istri sebagai teman/partner hidup suami, Istri sebagai penasehat yang bijaksa dan Istri sebagai pendorong suami

3. Wanita Sebagai Pekerja di Tengah Masyarakat

Secara kodrati, wanita sebagai manusia tidak dapat melepaskan diri dari keterikatannya dengan manusia lain. Seperti kita ketahui bahwa pada dasarnya berhubungan dengan individu lain merupakan suatu usaha manusia untuk memenuhi kebutuhan sosialnya. Dari hubungan antar pribadi ini, tumbuhlah perasaan diterima, ditolak, dihargai dan tidak dihargai dan diakui atau tidak diakui. Di samping itu dari hubungan antar pribadi ini, manusia dapat lebih mengenal dirinya sendiri, banyak mendapatkan penilaian dan memberikan penilaian. Bergaul dengan individu lain, membuka kesempatan bagi wanita untuk dapat menyatakan diri dan mengembangkan kemampuan 
untuk mengaktualisasi dirinya. Dalam hubungan antar pribadi (pergaulan) masing-masing individu diberi kesempatan untuk mengembangkan pribadinya untuk menghayati proses sosialisasi, menunjukkan prestasi dalam melakukan pekerjaan. oleh kaum feminis liberal oleh Narwoko (2007) mengatakan bahwa "memperjuangkan persoalan masyarakat tertuju pada kesempatan yang sama dan hak-hak yang sama bagi setiap individu termasuk didalamnya kaum perempuan".

\section{Dwi Narwoko}

(2007:346) mengatakan bahwa "gender menurut konsep structural fungsional dibentuk menurut pembagian peran dan fungsi masing-masing antara laki-laki dan perempuan secara dikotomi agar tercipta keharmonisan antara laki-laki dan perempuan". Oleh Talcott Parson 1959 (Ollenburger 2002) memaparkan bahwa "meningkatkan keahlian pekerja dan meningkatkan penghasilan individu, kaum fungsional menyimpulkan bahwa apabila suatu kelompok menderita ketidak semerataan disektor ekonomi, pemecahannya adalah meningkatkan modal manusia anggota-anggota kelompok itu melalui peningkatan pencapaian pendidikan".

Uraian tersebut bahwa anggota kelompok yang dimaksudkan adalah termasuk juga wanita dalam meraih pendidikan dan prestasi dalam melakukan pekerjaan sehingga mendapatkan kesejahteraan hak kebebasan bekerja atau berkarir bagi wanita, tetapi bukan berarti wanita melupakan peran yang mendasar yakni mengurus rumah tangga dan mengasuh anak-anaknya. Wanita bebas meraih prestasi dan bersaing dalam masyarakat karena untuk menunjukkan bahwa wanita juga punya semangat bekerja, mampu bersaing dan bisa diperdayakan. (Suhendi, 2001) mengatakan bahwa"gerakan yang mendorong wanita untuk bekerja diluar rumah didorong oleh semangat feminisme yang ada di Amerika yang memiliki pandangan bahwa semua orang diciptakan dengan hak yang sama untuk memajukan dirinya".

Terkait dengan hal tersebut, Asong dkk, 1996 (Pandu, M. 2006:64)

mengatakan bahwa "keadilan Gender adalah suatu keyakinan tentang kepercayaan bahwa setiap individu ksususnya perempuan diberikan kesempatan yang sama untuk berbuat yang terbaik berdasarkan kemampuan potensial yang ada pada diri mereka". Kemudian oleh (Pandu, 2006:64) juga menambahkan bahwa "keadilan gender seyogyanya berlaku baik dalam keluarga, masyarakat, lembagalembaga yang ada dalam masyarakat ditempat kerja dalam proyek pembangunan dan Negara dimana dalam keberlakuannya memperhitungkan keberadaan laki-laki dan perempuan berdasarkan nilai sosial budaya yang menjadi pedoman dan panutan dari masyarakat yang bersangkutan".

Uraian tersebut sangat jelas bahwa adanya kesetaraan antara kaum lakilaki dan wanita dalam perkembangan zaman sekarang, menjadikan wanita semakin berjuang dalam meraih pekerjaan sehingga mencapai kesuksesan seperti yang kita saksikan sekarang bahwa banyaknya wanita yang terjun dalam dunia pendidikan. Namun dengan kesuksesan wanita bekerja sering terjadi kerawanan komunikasi antara anggota keluarga (disorganisasi) dan sosialisasi dalam keluarga, karena kaum wanita cenderung meraih pekerjaan sebagai wanita karir atau wanita sukses dan itu merupakan kesuksesan yang tertinggi bagi kaum wanita. Oleh karena itu dengan kepadatan waktu bekerja bagi wanita, maka diharapkan kejelian 
wanita dalam mengatur waktu dan pola pengasuhan anak, sehingga tidak terjadi disorganisasi keluarga dan kebersamaan dengan anak-anak di rumah tidak terlalaikan.

Peningkatan angkatan kerja wanita tersebut menggambarkan bahwa pada masa kini, tentunya tenaga pekerjaan wanita akan semakin bertambah. Dengan demikian semakin hari wanita tidak lagi banyak berperan sebagai ibu rumah tangga (istri) di rumah saja, tetapi sudah banyak berperan dalam berbagai bidang kehidupan, baik sosial, ekonomi maupun politik. Wanita sekarang memiliki kesempatan yang lebih besar untuk bekerja dalam berbagai bidang pekerjaan yang dulu hanya dikuasai oleh pria, seperti manajer, mekanik, supir bus, dan polisi. Kesempatan yang lebih besar ini disebabkan semakin besarnya kesempatan bagi wanita Indonesia generasi sekarang untuk memperoleh pendidikan yang lebih tinggi. Wanita berpendidikan tinggi akan merasa siasia apabila gelar yang telah dicapainya tidak digunakan, sehingga banyak wanita yang memutuskan bekerja dan menjadi wanita bekerja.

Ini berarti bahwa perubahan yang dirancang kaum feminisme dalam memperbaiki kepentingan kaum wanita semakin meningkat, Marvin Harris, 1981 (Sanderson, 2003:424) mengatakan bahwa "tenaga kerja kaum wanita semakin dicari oleh kaum kapitalis untuk mengisi jumlah pekerjaan pelayanan dan informasi yang bertumbuh semakin cepat dalam perekonomian". Haris (Saderson, 2003:425) menambahkan pula akan keyakinannya bahwa "feminis moderen baik sebagai idiologi maupun sebagai gerakan sosial yang terorganisasi pada akhirnya dapat dijejaki keprubahan-perubahan ekonomi yang besar dimana kaum wanita semakin dilibatkan dalam dunia pekerjaan diluar rumah". Dengan memandang perubahan-perubahan selanjutnya, secepatnya garis-garis itu cenderung akan terjadi dalam dekadedekade yang akan datang, maka kekuasaan sosial dan kesadaran feminis dari jumlah kaum wanita yang semakin meningkat akan terus bertumbuh dan kaum wanita akan maju lebih jauh kearah persamaan sejati dengan kaum pria.

Melihat uraian tersebut bahwa perjuangan kaum wanita untuk bekerja diluar rumah semakin meningkat dan ini akan menjadikan wanita melakukan dua pekerjaan sekaligus, karena sekalipun wanita melakukan pekerjaan diluar rumah tangga yang cukup padat namun tidak menutup kemungkinan untuk meninggalkan pekerjaan dirumah seperti mengasuh anak dan menemani suami. Karena hal tersebut akan berdampak pada kerawanan dalam komunikasi antara anggota keluarga dan sosialisasi dalam keluarga. Dengan demikian wanita bekerja perlu menyediakan waktu yang cukup terutama waktu untuk anakanaknya. Dengan demikian dalam penelitian ini akan dilihat pola pengalokasian waktu bagi wanita bekerja dan pola mengasuhan anakanak di Rumah serta pola pengambilan keputusan dalam rumah tangga.

\section{B. Konsep Wanita Bekerja}

\section{Alasan Wanita Bekerja}

Dewasa ini banyak wanita disamping melakukan pekerjaan rumah tangga dan juga melakukan pekerjaan mencari nafkah, Suhendi, (2001) dengan alasan bahwa : a. Menambah pendapatan keluarga family income terutama jika pendapatan suami relative kecil, b. Memanfaatkan berbagai keunggulan (pendidikan, ketrampilan, modal dan relasi) yang dimilikinya dan diharapkan keluarganya, c. Menunjukkan eksistensi sebagai manusia (aktualisasi 
diri) bahwa ia mampu berprestasi dalam kehidupan masyarakat dan $\mathrm{d}$. Untuk memperoleh status atau kekuasaan lebih besar didalam kehidupan keluarga. Sejalan dengan itu, Munandar 1985 (Megawaty,2000:9) Mengatakan bahwa "wanita bekerja karena (1) Menambah penghasilan keluarga, (2) Secara ekonomis tidak tegantung pada suami, (3) Menghindari kebosanan dan mengisi waktu luang, (4) Mempunyai minat dan keahlian tertentu yang dimanfaatkan, (5) Memperoleh status dan penghargaan diri".

K. William, J. Goode, (2002:156) bahwa "ibu bekerja karena memang senang bekerja dan banyak kemungkinan merasakan adanya ikatan kuat, menjalankan disiplin relatif dan membebani mereka dengan pekerjaan rumah tangga". Todaro (Arif Budiman, 1995:9) mengatakan "bahwa faktor ekonomi terdapat beberapa unsur antara lain kesehatan, pendapatan atau penghasilan, perumahan, pendidikan". Hal ini jelas bahwa keadaan sosial ekonomi keluarga mempunyai peranan terhadap perkembangan anak-anak, karena dengan adanya perekonomian yang cukup, maka lingkungan material yang dihadapi anak-anak akan merasa terpenuhi, Faktor pendidikan, Berk (Moore, 1996:108), bahwa "dalam hal pekerjaan dirumah seperti pengasuhan anak, memberi makan dan pelayanan kebersihan, tampaknya fungsi secara langsung menguntungkan keluarga, namun demikian masih ada ibu rumah tangga melakukan aktivitas diluar rumah karena merasa terpanggil untuk mengabdikan diri kepada Negara sebab memiliki kemampuan baik dari segi ilmu pengetahuan (knowledge), ketrampilan (skill), sikap (attitude)".

Selain itu Oleh (Jacinta F. Rini, 2002) mengatakan bahwa faktor-faktor yang melandasi tindakan para ibu tersebut untuk bekerja di luar rumah atau motif-motif yang mendasari kebutuhan mereka untuk bekerja di luar rumah, hingga mereka mau menghadapi berbagai resiko atau pun konsekuensi yang bakal dihadapinya, antara lain : a) Dukungan Suami, b) Kehadiran Anak, c)Kebutuhan Finansial d) Kebutuhan Sosialrelasional dan e) Kebutuhan Aktualisasi Diri. Dengan demikian bahwa faktor-faktor yang mempengaruhi wanita bekerja dan berumah tangga semata-mata karena dukungan suami sebagai kepala rumah tangga disamping itu karena kehadiran anak yang menjadi tanggungan sehingga semakin banyak kebutuhan rumah tangga. Disamping membantu suami mencari nafkah, maka sebagai wanita yang berpendidikan tinggi tentu wanita ingin mengembangkan diri mereka sehingga pengetahuan mereka dapat dimanfaatkan.

\section{Kendala Wanita Bekerja}

Adapun yang menjadi kendala wanita bekerja dalam mengasuh anakanaknya adalah Keterbatasan waktu dan Kesibukan di Luar Rumah sehingga sangat mengganggu kebersamaan dengan anak-anak dirumah, karena semakin sering anak ditinggalkan sama tetangga atau pembantu akan memberi kesedihan bagi seorang ibu

\section{Pembagian Peran Antara Suami dan Isteri}

Pekerjaan dalam rumah tangga memang tidak dapat disangkal lagi oleh kaum wanita mulai dari mencuci pakaian, menyetrika, membersihkan rumah, memasak serta menyediakan makanan sampai mencuci piring, hal ini akan menyita banyak waktu jika dilakukan sendirian. Selain itu diperhadapkan lagi dengan melahirkan, menyusui dan mengurus anak-anak, yang memang tidak bisa dielakkan oleh kaum wanita, karena itu Arif Budiman, (1985:1) mengatakan bahwa :"Banyak 
orang percaya bahwa wanita sudah sewajarnya hidup dilingkungan rumah tangga dengan tugas yang diberikan alam kepada mereka yakni melahirkan dan membesarkan anak didalam rumah tangga serta memasak dan memberi perhatian pada suaminya supaya sebuah rumah tangga yang tentram dan sejahtera dapat diciptakan".

Searah dengan itu teori fungsionalis olehTalcot Parson tokoh dari aliran fungsionalis di Amerika serikat yang oleh Arif Budiman (1985:16) mengatakan bahwa: "Wanita harus bekerja didalam rumah tangga, maka ditiadakan kemungkinan terjadinya persaingan antara suami dan istri, pembagian kerja secara seksual ini bahwa suami mengembangkan karirnya diluar rumah, sang isteri didalam rumah, isteri boleh bekerja diluar rumah tetapi itu bukan merupakan karirnya, sehingga kemungkinan tidak terjadinya persaingan antara suami dan isteri dan memperjelas fungsi suami dan isteri dalam keluarga inti dan memberikan rasa tenang bagi keduanya".

Uraian tersebut terlihat bahwa pembagian kerja antara suami dan isteri dalam rumah tangga atau keluarga inti akan terciptanya keharmonisan dalam rumah tangga dan memberikan rasa tenang dan saling menghargai tanpa adanya persaingan antara suami dan isteri. Pembagian peran ini didasarkan pada perbedaan psikologi antara lakilaki dan wanita yang oleh Skolnick (Arif Budiman, 1985:3) menyebutkan teori Nature dan teori Nurture, pengikut teori Nature beranggapan bahwa perbedaan psikologi antara laki-laki dan wanita disebabkan oleh faktor-faktor biologis kedua insan ini, sedang pengikut teori Nurture menganggap bahwa perbedaan ini melalui proses belajar dari lingkungan. Selanjutnya dalam pendekatan struktural fungsional juga menggunakan konsep sistem, dimana sistem sosial merupakan pola yang mengantar hubungan timbal balik antara individu yang satu dengan individu yang lain dan antara individu dengan masyarakat lainnya. (Soekanto, 1990:264).

Ini berarti bahwa peranan sosial seperti suami dan isteri merupakan realitas sosial terkecil yang membentuk suatu sistem sosial sehingga keluarga dapat dipandang sebagai suatu sistem sosial yakni struktur atau bagian yang saling dihubungkan status dan peranan timbal balik suami isteri dan anak mereka. Sedangkan Suhendi, $H$. Wahyu, R, (2001:175) mengatakan bahwa : "Melihat adanya disorganisasi keluarga atau tidak bagi wanita yang melakukan pekerjaan diluar rumah tangga atau peran ganda, maka digunakan teori fungsionalisme structural yang menekankan pada keteraturan (order) dan mengabaikan konflik dalam masyarakat, dimana konsep utamanya adalah fungsi, disfungsi, fungsi laten, fungsi manifest dan keseimbangan (equilibrium)". Keluarga dianggap sebagai masyarakat kecil yang terdiri dari subsistem yang berstruktur yakni anggota keluarga yang terdiri dari ayah, ibu dan anak yang memiliki hubungan antara satu sama lain yang menyatu dalam keluarga. Setiap bagian dalam keluarga bersifat fungsional terhadap yang lain. Ayah berfungsi untuk mendapatkan penghasilan bagi keluarga dan mencari nafkahpun dibebankan kepada ayah. Fungsi laki-laki ini disebut fungsi maniferst yaitu peran yang diharapkan terjadi pada ayah sebagai bagian dalam keluarga. Sedangkan fungsi latens belum terlihat jelas dan anak belum merupakan suatu individu yang berdiri sendiri yang dapat kontak langsung dengan lingkungan. Ini berarti bahwa pengasuhan anak dalam keluarga diharuskan peran ayah atau ibu samasama menjalankan fungsinya. Adanya peran dan fungsi secara adil ini tentu 
akan membawa pertumbuhan anak menjadi orang yang mandiri dan sesuai harapan kita semua, karena adanya fungsi dan peran antara kedua orang tua yakni ayah dan ibu dalam mengasuh anak-anaknya.

\section{Wanita Bekerja dan Pengambilan Keputusan}

Pola pembagian kerja juga didasarkan pada proses pengambilan keputusan. Rabihatun (1996:185) mengatakan bahwa : "Proses pengambilan keputusan dalam rumah tangga antara suami dan istri lebih banyak ditentukan oleh norma yang berlaku dalam tiap-tiap rumah tangga yang biasanya didasarkan pada pandangan keagamaan atau adat istiadat setempat". Ini berarti bahwa sepanjang norma itu tidak menimbulkan permasalahan maka dalam rumah tangga tidak dipersoalkan, namun tidak menutup kemungkinan sebagian rumah tangga yang slalu mempersoalkannya misalnya wanita hanya menjadi pelengkap tetapi bukan pemeran utama dalam memberikan keputusan maka akan muncul persoalan seperti contoh dalam hasil penelitian Simatau dkk (2000) mengangkat kasus Timika di Arso, di Kalimantan dan banyak dibelahan dunia lainnya memperlihatkan bahwa "ketika perempuan tidak mempunyai control atas pengambilan keputusan menyangkut masa depan wilaya kelola maka perempuan terseret dan tenggelam dalam berbagai persoalan, turunya status kesehatan, anjloknya perekonomian keluarga, tertutupnya akses terhadap informasi, kekerasan, beban kerja berlebihan adalah persoalan yang secara khusus menimpah perempuan diwilayah konflik manapun".

Uraian tersebut jelas bahwa keadilan gender dalam pola pengambilan keputusan ternyata membawa manusia pada posisi kesetaraan dan keseimbangan antara laki-laki dan wanita dalam proses menentukan keputusan secara bersama yaitu pengambilan keputusan dibatasi pada siapa yang mengelolah penghasilan suami maupun penghasilan istri, siapa yang menentukan menu stiap hari, siapa yang menentukan pembelian prabot dan siapa yang menentukan pendidikan mana yang diikuti dan lain sebagainya. Dengan begitu keadilan dan keharmonisan dalam rumah tangga semakin meningkat. Sajogyo, (2002:71) mengatakan bahwa "peranan wanita dalam pengambilan keputusan baik dalam rumah tangga maupun dalam masyarakat dilihat dalam konteksnya dengan pembagian kekuasaan dan wewenang antar jenis kelamin dan antar kelas".

\section{Pembangunan dan Pemberdayaan Wanita}

Siagian, (Makaenas, 2005: 19) mendefinisikan pembangunan adalah "suatu usaha atau rangkaian usaha pertumbuhan dan perubahan yang berencana yang dilakukan secara sadar oleh suatu bangsa, Negara dan pemerintah menuju modenitas dalam rangka pembinaan bangsa”. Budiman.A, (1995:13) mengatakan bahwa "pembangunan meliputi dua unsur pokok yakni: (1) masalah materi yang mau dihasilkan dan yang mau dibagi, (2) Masalah manusia yang menjadi pengambilan inisiatif yang menjadi manusia pembangunan". Makna penting dari pembangunan dinyatakan pula oleh Tikson (Makaenas, 2005:4) bahwa "adanya kemajuan/perbaikan (progress), pertumbuhan dan difersifikasi”. Kemajuan misalnya dapat diidentifikasi dari adanya peningkatan dalam rasionalisasi kehidupan masyarakat, teknologi dan efisien. Sedangkan pertumbuhan identik 
dengan kemajuan ekonomi yang ditandai dengan peningkatan pendapatan masyarakat sebagai akibat dari kenaikan produktivitas yang berkelanjutan, yang diikuti oleh difersifikasi kegiatan ekonomi. Sedangkan oleh Jamasy, (2004:7) mengatakan bahwa "sebagai jawaban terhadap persoalan ini, maka muncul konsep pembangunan yang menjadikan manusia sebagai pusat perhatian dimana dikenal sebagai pembangunan masyarakat".

Pembangunan adalah merupakan proses perubahan sosial, dimana perubahan yang dimaksud adalah suatu perubahan yang disengaja atau yang direncanakan dengan tujuan untuk mengubah keadaan yang tidak di kehendaki kearah yang dikehendaki. Sehingga Raharjo, (1999:92) ada pula yang mendefinisikan pembangunan sebagai usaha yang dilakukan secara sadar untuk menciptakan perubahan sosial melalui modernisasi”.

Searah dengan itu, Perempuan dan pembangunan (W.A.D) merupakan pendekatan feminis neo-Marxis, yang muncul dalam paruh terakhir 1970 an yang berasal dari suatu kepedulian terhadap keterbatasan teori modenisasi, bukannya menitikberatkan kepada strategi untuk mengintegrasikan perempuan dalam pembangunan, tetapi Pandu, M. (2006) mengatakan bahwa "pendekatan ini justru menunjukkan bahwa perempuan selalu penting secara ekonomi dan kerja yang dilakukan dalam rumah tangga dan komunitasnya sangat mendasar untuk mempertahankan masyarakat mereka". Salah satu upaya yang dilakukan oleh pemerintah dalam rangka mengoptimalkan potensi wanita adalah melalui pemberdayaan wanita. Bainer dan Halik, (Makaenas, 1999:27). Mengatakan bahwa :"Tujuan pembangunan wanita adalah peningkatan keterjangkauan (akses) wanita kepada sumber dan manfaat pembangunan, meningkatkan kesadaran wanita tentang diskriminasi gender, meningkatkan pertisipasi aktif para wanita, meningkatkan penguasaan wanita terhadap sumber dan manfaat pembangunan dan menjadikan wanita mandiri dalam arti ekonomi, sosial, budaya secara sosiologis".

Asumsi tersebut jelas bahwa pemberdayaan wanita tidak saja bertujuan untuk membuka akses bagi wanita terhadap sumber daya, mengeliminir diskriminasi dan melibatkan wanita dalam pembangunan, semata tetapi partisipasi atau peran ganda wanita dalam pembangunan umumnya bertujuan untuk meningkatkan taraf kehidupannya dalam mencapi kesejahteraan keluarga.

\section{Metode Penelitian}

Penelitian ini bersifat deskriptif dengan pendekatan studi kasus,. Dalam memperoleh data dan informasi yang dibutuhkan digunakan teknik Observasi, Wawancara Mendalam dan Dokumentasi. Informan sebanyak 8 orang yang ditentukan secara purposive sampling. Analisis data ditelaah dan dipelajari serta direduksi dengan cara menyusunnya dalam satuan-satuan kemudian dikategorikan secara sistimatis pemeriksaan keabsahan data, kemudian terakhir adalah penafsiran secara obyektif dan menyimpulkannya.

\section{Hasil Penelitian}

\section{A. Keadaan Wanita Bekerja}

Dari 8 guru wanita rata-rata berusia antara 30-48 tahun dan merupakan usia wanita yang umumnya telah berumah tangga dan memiliki anak, kemudian pendidikan rata-rata $S 1$ namun hanya 1 orang yang Sarjana Muda. Statusnya ratarata telah manikah dan hanya 1 orang yang telah bercerai (janda), kemudian Golongannya tercatat 3 orang yang golongan IV/a, 2 orang golongan III/b dan 
3 orang golongan III/a. Kemudian pendapatannya sesuai dengan golongan masing-masing

\section{B. Kasus 8 Wanita Bekerja dan Ibu \\ Rumah Tangga}

Berdasarkan hasil pembahasan 8 kasus wanita bekerja dan ibu Rumah tangga tersebut, menunjukkan bahwa latar belakang ekonomi keluarganya rata-rata petani sawah dan hanya 1 orang yang berasal dari keluarga yang orang tuanya pegawai Negeri. Walaupun berlatar belakang dari keluarga petani sawah, namun rata-rata semua saudara 8 orang wanita bekerja tersebut memiliki kemauan untuk sekolah sampai sarjana dan tidak lagi bertani seperti halnya orang tua mereka masing-masing.

Kemudian setelah menikah sebagian besar 8 wanita bekerja tersebutmemiliki tanah sawah sebagai penghasilan tambahannya walaupun terlihat bekerja sebagai guru PNS dan memiliki gaji tetap. Hal tersebut terlihat hanya 2 orang ibu rumah tangga yang tidak memiliki tanah sawah dan 5 orang ibu rumah tangga memiliki tanah sawah, namun hanya 1 orang ibu rumah tangga yang tidak langsung kesawah walaupn memiliki tanah sawah namun dipercayakan kepada orang lain untuk bekerja dengan syarat bagi hasil.

Dalam mengerjakan tugas dan tanggungjawab suami dan isteri tersebut dalam rumah tangga 8 kasus wanita bekerja tersebut terlihat bahwa tentunya ada pembagian kerja dalam rumah tangga, sehingga tidak adanya persaingan atau saling berharap antara satu sama lainnya. Searah dengan itu teori fungsionalis oleh Talcot Parson tokoh dari aliran fungsionalis di Amerika serikat yang oleh Arif Budiman (1985:16) yang dipaparkan diatas mengatakan bahwa: "Wanita harus bekerja didalam rumah tangga, maka ditiadakan kemungkinan terjadinya persaingan antara suami dan istri, pembagian kerja secara seksual ini bahwa suami mengembangkan karirnya diluar rumah, sang isteri didalam rumah, isteri boleh bekerja diluar rumah tetapi itu bukan merupakan karirnya, sehingga kemungkinan tidak terjadinya persaingan antara suami dan isteri dan memperjelas fungsi suami dan isteri dalam keluarga inti dan memberikan rasa tenang bagi keduanya.

Dengan demikian bahwa pembagian kerja dalam rumah tangga yang oleh teori fungsionalis oleh Talcot Parson dikemukakan pula pada kasus 8 orang guru wanita bekerja di Desa karumbu, namun tidak terjadi pembagian peran yang sangat ketat antara keduanya, karena seorang isteri disamping bekerja sebagai guru maka juga mengurus rumah tangga dan anak-anaknya serta menemani suami mengurus persawahan, begitu juga suami disamping bekerja sebagai guru atau sejenisnya tetapi juga mengurus persawahan dan menemani anaknya belajar pada malam hari, tetapi setelah selesai mengurus persawahan terkadang suami juga membantu isteri mengurus rumah tangga seperti menyapu halaman, bermain dengan anak-anak dan menyiram bunga-bunga, hal tersebut dilakukan sehingga terhindar dari persaingan antara keduanya.

\section{Alokasi Waktu Wanita Bekerja}

Alokasian waktu 8 kasus wanita bekerja dan ibu rumah tangga tersebut menunjukkan bahwa alokasi waktu yang digunakan sebanyak 24 jam dalam sehari terlihat 6 orang wanita yang rata-rata menggunakan waktu untuk bekerja di luar rumah (peran publik), sebanyak 6 jam (25\%), karena jarang mengikuti kegiatan social masyarakat, 1 orang wanita yang menggunakan waktu untuk peran publik sebanyak 9 jam (38\%) karena disamping mengajar tetapu juga aktif dalam kegiatan social masyarakat, dan 1 orang wanita menggunakan waktu untuk peran publik sebanyak 8 jam (33\%) karena aktif juga dalam kegiatan sosial masyarakat

Dalam melakukan peran domestik terlihat juga bahwa dari 8 kasus tersebut 
yang menggunakan waktu $29 \%$ bagi wanita yang telah memiliki anak yang bisa diajak membantu dalam melakukan pekerjaan rumah, yang menggunakan waktu $37 \%$ bagi ibu yang masih memiliki anak kecil, mengurus pekerjaan rumah dan juga membantu suami dalam mengurus persawahan, yang menggunakan waktu $33 \%$ bagi ibu yang hanya mengurus pekerjaan rumah saja dan memiliki anak kecil yang harus ditemaninya, sedangkan yang menggunakan waktu $20 \%$ bagi wanita yang banyak berperan diluar rumah dan untuk kerja dirumah sangat sedikit karena suami juga terlibat dalam mengurus makanan jika isteri tidak ada. Kemudian yang menggunakan waktu $17 \%$ bagi ibu yang memiliki pembantu rumah tangga dan hanya bermain dengan anaknya saja.

Untuk waktu istirahat terlihat bahwa yang menggunakan waktu $33 \%$ karena hanya 1 jam pada siang hari dan 7 jam pada malam hari, yang menggunakan waktu $25 \%$ karena tidak memiliki waktu istirahat pada siang hari dan hanya 6 jam istirahat pada malam hari, yang menggunakan waktu 29\% karena walaupun tidak memiliki waktu istirahat pada siang hari namun 7 jam waktu istirahat pada malam hari, yang menggunakan waktu $45 \%$ karena memiliki waktu istirahat 3 jam pada siang hari dan 8 jam pada malam har, sedangkan yang menggunakan waktu $34 \%$ karena memiliki waktu istirahat 1 jam pada siang hari dan 7 jam pada malam hari. Sedangkan waktu untuk digunakan untuk digunakan dalam kegiatan individual rata-rata $13 \%$ karena hanya digunakan untuk ibadah.

Dengan demikian alokasian waktu wanita bekerja dan ibu rumah tangga ternyata lebih banyak waktu yang digunakan untuk bekerja baik yang bersifat publik maupun yang bersifat domestik dari pada waktu istirahat, apalagi bagi ibu yang memiliki anak kecil, sangat sedikit waktu untuk istirahat jika tidak ada yang membantu dalam melakukan pekerjaan rumah tangga. Hal ini di perjelas pula oleh
Bastian (Rabihatun, 1996:22) juga mengatakan bahwa "Tenaga kerja wanita ternyata menggunakan alokasi waktu lebih besar dari pada tenaga kerja laki-laki, karena selain kegiatan dalam rumah tangga, juga wanita melakukan kegiatan produktif diluar rumah tangga, yakni Waktu untuk bekerja di rumah dan waktu untuk mengatur rumah tanggannya meliputi kegiatan memasak, mencuci, membersihkan rumah dan halaman, mengasuh anak, dan waktu senggangnya digunakan untuk istirahat.

\section{Pengambilan Keputusan Wanita Bekerja}

Pola pengabilan keputusan 8 kasus tersebut cukup terbuka antara suami dan isteri, dan penghasilan rata-rata dipercayakan sama isteri untuk memegang keuangan walupun dikelolah secara bersama, namun kurang melibatkan anakanak dalam pengambilan keputusannya. Pengambilan keputusan yang berkaitan dengan rumah tangga 8 kasus wanita bekerja tersebut terlihat bahwa rata-rata pengambilan keputusan lebih cenderung setara pada penentuan pembelian rumah, pendidikan anak dan kesehatan, pembelian alat rumah tangga, rekreasi, pembagian kerja dalam rumah tangga, disiplin anakanak dan menetapkan jumlah anak, perhiasan atau emas, mengikuti acaraacara resmi dan pembelian sarana pencaharian. Sedangkan pada kegiata yang berkaitan dengan konsumsi makanan setiap hari dan pakaian terlihat bahwa wanita lebih dominan. Oleh M.R, selaku kepala sekolah SMP Negeri 1 Langgudu mengatakan bahwa "Dalam sebuah rumah tangga diharuskan Isteri yang memegang keuangan (bendahara) dalam rumah tangga, sedangkan suami cukup memegang uang sesuai dengan kebutuhan hari-harinya, namun pengelolaan dibicarakan secara bersama dan kalau kebutuhan rumah tangga terlalu banyak dilibatkan laki-laki (suami) dalam menentukan atau mengatur perabot rumah tangga, menu makan setiap hari dan 
pakaian, maka akan berimbas kepada tidak berkahnya rumah tangga kami dan selalu ditimpah berbagaimacam masalahdan juga dianggap sebagai laki-laki (suami) yang kikir dan kurang menginginkan keharmonisan keluarga". (Wawancara, 28 Maret 2010)

Kemudian oleh RM, yang juga suami dari salah satu responden menambahkan bahwa:"laki-laki (suami) merasa malu jika terlalu terlibat dalam urusan rumah tangga seperti mengatur menu makanan, mengatur perabot rumah yang didapur dan memegang uang karena akan dianggap suami jajirami de dalam bahasa bima.Maksudnya suami tidak baik, pelit, banyak perhitingannya dan kurang membawa keberuntungan dalam rumah tangga". (Wawancara, 29 Maret 2010)

Ini berarti pengambilan keputusan dalam rumah tangga dari 8 kasus wanita bekrja tersebut terlihat cukup setara dan selalu dimusyawarakan antara suami dan isteri sebelum melakukan sesuatu, namun kurang melibatkan anak dalam pengambilan keputusan.

\section{Kesimpulan}

Berdasarkan hasil penelitian yang telah diuraikan dalam pembahasan diatas, maka dapat ditarik kesimpulan adalah :

1. Pola pengasuhan anak yang diterapkan dalam keluarga 8 kasus rumah tangga wanita bekerja dan ibu rumah tangga tersebut terlihat rata-rata pola pengasuhan anaknya cenderung otoriter karena penentuan jadwal kegiatan berpihak pada orang tua, kemudian kebersamaan dengan anakanak di rumah sangat terbatas karena diperhadapkan dengan pekerjaan baik pekerjaan di luar rumah (peran publik) maupun pekerjaan dalam rumah tangga (peran domestik) dan juga terlihat 4 orang yang memiliki kerja tambahan yakni membantu suami mengurus persawahan.

2. Pola pemanfaatan waktu 8 kasus wanita bekerja dan ibu rumah tangga terlihat sangat padat dan lebih banyak menghabiskan waktu bekerja dari pada bersama dengan anak-anak atau waktu untuk istirahat.

3. Pola pengambilan keputusan 8 kasus wanita bekerja dan ibu rumah tangga tersebut terlihat cukup setara dan adanya keterbukaan antara suami dan isteri, namun pada pengaturan menu makanan atau pakaian serta bendahara keuangan lebih dominan pada wanita, hanya terlihat kurang melibatkan anakanak dalam mengabilan keputusan.

\section{Daftar Pustaka}

Ahmadin, 1991. Sosiologi Pendidikan, Rineka Cipta, Jakarta

Boserup, Ester, 1984. Peran Perempuan Dalam Pembangunan Ekonomi, Jakarta; Yayasan Obor Indonesia

Budiman, A. 1985. Pembagian Kerja Secara Seksual Sebuah Pembahasan Sosiologis Tentang Peran Wanita Dalam Masyarakat, PT. Gramedia: Jakarta

, 1995. Teori Pembangunan Dunia Ke Tiga, Gramedia Pustaka Utama, Jakarta.

Dwi, J. Narwoko, 2007. Sosiologi Teks Pengantar dan Terapan, Cet. 3, Kencana, Jakarta

Goode, William J, 2002. Sosiologi Keluarga, Cet. V; Bumi Aksara, Jakarta

Hania Hamid, 2004. Studi Ter hadap Guru SMK 6 Makassar. Disertasi Program Pascasarjana, Universitas Negeri Makassar.

Hamid, Abu, 2007. Sosiologi Pendidikan, Cet. II, Rineka Cipta, Jakarta

Ihromi, T.O. 1990. Laporan Penelitian Para Ibu yang Berperan Tunggal dan yang Berperan Ganda. Kelompok Studi Wanita FISIP-UI. Lembaga Penerbitan Fakultas Ekonomi UI, Jakarta.

Jacinta F. Rini Team, 2002. Wanita Bekerja Jakarta, (Online) (http://denmasgoesyono.multiply.com/ 
reviews/item/2,jakarta)diakses:

20

September 2009)

Kissanti A, 2008. Buku Pintar Kesehatan Dan Tumbuh Berkembang Anak, Araska printiuka, Yogyakarta

Makaenas, S. 2005. Peran Wanita Dalam Keluarga Nelayan : Studi Kasus Dikelurahan Baurung Kecamatan Banggae Kabupaten Majene, Makassar, Disertasi Program Pascasarjana PK-UNM

Megawaty, AP, 2000. Pola Pengasuh Anak Pada Ibu Rumah Tangga Bekerja Di Kotamadya Makassar (Kasus Perumnas Bumi Tamalanrea Permai, Tesis Program Pascasarjana, Universitas Hasanuddin, Makassar.

Narwoko, J.D.,Suyanto,B (2007). Sosiologi Teks Pengantar dan Terapan, Cet. 3, Kencana; Jakarta

Nurland, F. 1993. Alokasi Waktu Bagi Wanita Etnis Bugis, Makassar dan Mandar. Disertasi, Program Pascasarjana, Universitas HasanudinIPB, Makassar.

Ollenburger, J. C., Moore, H, A. 2002. Sosiologi Wanita (A Sosiology Of Women), Cet. 2, Rineka Cipta, Jakarta. Rabihatun, I. 1996. Analisis Angkatan Kerja Wanita Pada Masyarakat Perkotaan Di Sulawesi Selatan. Tesis Program Pascasarjana, Universitas Hasanuddin, Ujung Pandang

Ritzer George, 2007. Teori Sosiologi Moderen, Cet. 4, Ed: 6 Kencana; Jekarta

Robinson, Philip, 1986. Beberapa Perspektif Sosiologi Pendidikan, CV. Rajawali, Jakarta

Sajogyo, 2002. Sosiologi Pedesaan Kumpulan Bacaan, Ed. 2, Cet. 11. Gadja Mada University Press. Yogyakarta

Sanderson, Stephen K, 2003. Makro Sosiologi Sebuah Pendekatan Terhadap Realitas Sosial, Ed. 2 Cet. 4, Rajawali Pers, Jakarta

Shadily, Hasan. 1983. Sitematika, Teori dan Terapan, Jakarta Bumi Aksara
Suhendi, H., Wahyu R, 2001. Pengantar Studi Sosiologi Keluarga, Pustaka

Yin, Robert K. 2006. Studi Kasus Desain dan Metode, PT. Raja Grafindo Persada, Jakarta. 